\title{
PERANAN PT. PERMODALAN EKONOMI RAKYAT (PER) DALAM PENINGKATAN EKONOMI MASYARAKAT DI PROVINSI RIAU
}

\author{
Fahrial $^{1)}$, Rini Fatriani ${ }^{2)}$ Jenita $^{3)}$ \\ ${ }^{1}$ Dosen Faperta Agribisnis UIR, ${ }^{2}$ Dosen STIE Riau, ${ }^{3}$ Dosen UIN Riau \\ Email : fahrial2018@agr.uir.ac.id ${ }^{1}$,rinifatriani@yahoo.co.id, \\ jenitadjasman@gmail.com
}

\begin{abstract}
PT. PER as society wervice institution and PAD source in the economic crisis condition still exist and felt its role. The people economic improvement faces complex problem. The activities in the real sectors grow and will need huge capital. The role of PT. PER will be importanc in improving the society economic. The society economic development and improvent faces complex problem such as : the difficulty in accessing capital, the low of human resoureces quality, the limited technology mastering, the wenk management (financial and marketing), the low quality product and the weak institution and the institution arrangement in developing and empowering the people economic still non optimum. In the problems formulation, the writer discloseded qualitative and quatitative data. The results tried to describe the phenomenon about the PT. PER roles in improving the society economic at Riau Province. The results showed that during four years operation, ther is credit channeling improvement from year to year. PT. Permodalan Ekonomi Rakyat (PER) able to be "agent of development" in the economic recovery, able to distribute economic factors more evenly to people and has big multiplier effect. With PT. PER presence, the micro, small, middle business and cooperative and financial institution of Bank (BPR/S) and micro financial institution (UEK/D-SP), BMT) farmer group and other that formerly difficult to obtained business capital able to access PT. PER.The othe positive impact is PT. PER also contribute in illuminating the society attitude become bank minded.
\end{abstract}

Keywords: institution, society economic, micro financial and agent of development

\section{PENDAhULUAN}

PT. Permodalan Ekonomi Rakyat (PER) adalah Lembaga Keuangan Non Bank atau Modal Ventura yang merupakan Badan Usaha Milik Daerah (BUMD) Provinsi Riau (Perda No. 19 Tanggal 27 Desember 2002) yang bergerak dalam mengembangkan dan memberdayakan ekonomi rakyat di Provinsi yang dalam operasionalnya melekat dua fungsi, yaitu sebagai unsur pelayanan masyarakat dan sebagai salah satu sumber PAD.
Sebagai unsur pelayanan masyarakat dituntut berorientasi sosial, sedangkan sebagai sumber PAD tidak terlepas dari aspek ekonomi, yaitu mencari keuntungan. Banyak Badan Usaha Milik Daerah (BUMD) belum mampu memenuhi tuntutan tersebut, karena keterbatasan di bidang keuangan, operasional, dan administrasi. Sebagaimana dikemukakan oleh Alhabsji dkk (1987 : 2) bahwa belum berperannya perusahaan daerah sebagaimana yang diharapkan disebabkan oleh tiga 
masalah pokok, yaitu masalah keuangan, personalia, dan pengawasan.

Pengalaman menunjukkan, dalam kondisi krisis ekonomi yang berkepanjangan, ternyata ekonomi rakyat masih eksis dan dirasakan peranannya. Ketika usaha-usaha besar memberikan penghasilan paspasan kepada karyawannya, mereka masih bisa hidup karena dukungan sektor informal dan usaha kecil disekitarnya seperti warung tegal, kaki lima dan sejenisnya. Karena itu, ekonomi rakyat dapat disebut sebagai "bantal pengaman" pemulihan ekonomi. Meskipun demikian, pengembangan dan peningkatan ekonomi rakyat menghadapi permasalahan yang kompleks antara lain: kesulitan memperoleh modal, rendahnya kualitas sumber daya manusia, terbatasnya penguasaan teknologi, lemahnya manajemen (keuangan dan pemasaran), rendahnya kualitas produk yang dihasilkan dan kelemahan institusi serta penataan kelembagaan dalam mengembangkan dan memberdayakan ekonomi rakyat masih belum optimal. Meskipun jumlah Bank cukup banyak beroperasi di Provinsi Riau, tetapi masih banyak pelaku ekonomi rakyat yang belum berhasil memperoleh kredit dengan mudah dan cepat.

Peranan PT. PER akan menjadi penting untuk dilaksanakan pada saat ini karena di dalam menentukan kebijakan alokasi anggaran sebagai penyertaan modal Pemerintah Daerah pada perusahaan daerah yang berprinsip ekonomi, efisien dan efektif akan dapat terpenuhi apabila tingkat kesehatan perusahaan tersebut dinilai baik sesuai dengan kriteria yang ditentukan.

Penelitian ini diharapkan dapat memberi petunjuk langkahlangkah kebijakan yang perlu diambil dalam mengembangkan PT. PER sebagai salah satu sumber PAD dan sebagai agen pembangunan ekonomi di Provinsi Riau selain itu untuk melihat sampai sejauh mana Peranan PT. PER ini dalam meningkatkan ekonomi masyarakat.

\section{KERANGKA PEMIKIRAN DAN KERANGKA TEORI}

A. Kerangka Pemikiran

Peran strategis BUMD sebagai korporasi yang sangat diperlukan dalam mendukung pembangunan Nasional dan daerah masih belum maksimal karena menghadapi beberapa kendala dan permasalahan yaitu banyaknya BUMD yang merugi dan rendahnya kwalitas pelayanan public seperti pengelola bisnis \& manajemen yang kurang professional dan cendrung birokratis, besarnya intervensi Pemerintah Daerah terhadap kebijakan dan pengelolaan bisnis BUMD. Perannya BUMD dapat dilihat pada gambar 1 sebagai berikut: 
Gambar 1.

Permasalahan PT. PER

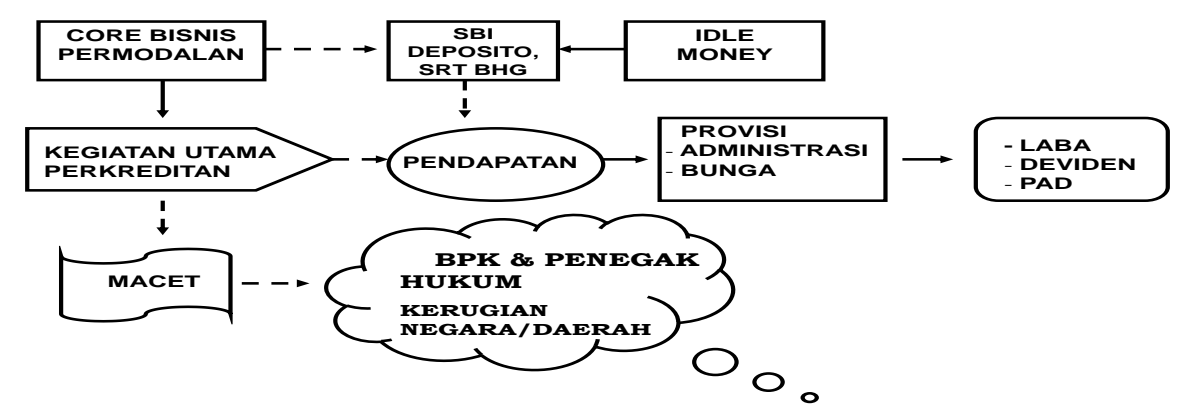

Sumber : Data olahan, 2019

Untuk mengatasi permasalahan di atas BUMD harus melakukan segala upaya untuk meningkatkan kinerja usahanya serta melakukan sosialisasi mengenai prestasi dan keberhasilan upaya peningkatan kinerja perusahaan dan peranannya dalam meningkatkan ekonomi masyarakat.

Eksistensi PT. PER Provinsi Riau mempunyai fungsi pokok pelayanan umum masyarakat dan sebagai salah satu sumber PAD. Dalam menjalankan fungsinya tersebut harus mampu membiayai dirinya sendiri dan harus berusaha mengembangkan tingkat pelayanan kepada masyarakat, artinya setiap usaha yang dijalankan harus dapat menghasilkan keuntungan yang dapat digunakan untuk operasionalisasinya dan selebihnya untuk membiayai kegiatan pembangunan daerah menyangkut aspek kehidupan masyarakat lainnya.

Gambar 2.

Peranan PT. PER sebagai Lembaga Keuangan

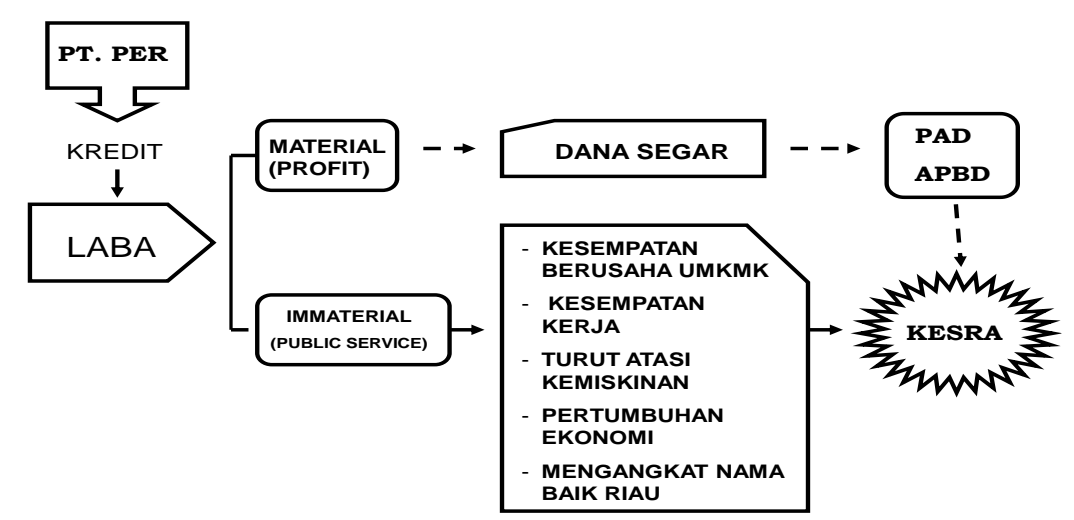

Sumber : Data Olahan, 2019 
Dari gambar 2 menggambarkan PT. PER Provinsi Riau mempunyai 2 (dua) peranan penting dalam menjalankan kegiatan usahanya yaitu memberikan profit (material) dan immaterial (public service). Artinya peranan PT. PER tidak harus mencari keuntungan dalam bentuk kontribusi Pendapatan Asli Daerah (PAD) sebagai APBD yang secara tidak langsung dapat meningkatkan kesejahteraan atau ekonomi masyarakat dan secara langsung harus memberikan pengaruh dalam peningkatan ekonomi masyarakat melalui kredit yang salurkan sehingga dapat memberikan kesempatan berusaha bagi UMKMK, kesempatan kerja, turut atasi kemiskinan, pertumbuhan ekonomi dan mengangkat nama baik Riau. Saat ini PT. PER masih belum mampu memenuhi baik tuntutan masyarakat maupun pembangunan daerah secara optimal.

\section{B. Kerangka Teori.}

Alhabsji dkk, (1987: mengemukakan bahwa berperannya perusahaan daerah sebagaimana yang diharapkan disebabkan oleh tiga masalah pokok, yaitu masalah keuangan, personalia, dan pengawasan. Masalah keuangan yang dihadapi oleh perusahaan daerah adalah kekurangan modal untuk investasi, sedangkan masalah penunjang yang cukup berpengaruh terhadap kinerja perusahaan daerah adalah profesionalisme sumber daya manusia yang masih rendah, dan tingkat pengawasan yang masih rendah.

Devas dkk, mengemukakan bahwa Pemerintah Daerah mendirikan perusahaan daerah atas dasar pertimbangan: menjalankan ideologi yang dianutnya bahwa sarana produksi milik masyarakat; melindungi konsumen dalam hal ada monopoli alami; dalam rangka mengambil alih perusahaan asing; menciptakan lapangan kerja atau mendorong pembangunan ekonomi daerah; dianggap cara yang efisien untuk menyediakan layanan masyarakat, dan/atau menebus biaya, serta menghasilkan penerimaan untuk Pemerintah Daerah.

Berdasarkan Keputusan Menteri Dalam Negeri Nomor 690-069 tahun 1992, tentang Pola Petunjuk Teknis ditegaskan bahwa Perusahaan Daerah mempunyai fungsi pokok pelayanan umum kepada masyarakat, sehingga di dalam menjalankan fungsinya tersebut Perusahaan Daerah harus mampu membiayai dirinya sendiri dan harus berusaha mengembangkan tingkat pelayanan dan diharapkan mampu memberikan sumbangan kepada Pemerintah Daerah dalam fungsinya sebagai sumber Pendapatan Asli Daerah (PAD).

Menurut Bayu (2002:4) yang dapat dilakukan adalah mengusahakan mencoba mengusahakan agar kebijakan pemberdayaan ekonomi rakyat tersebut dapat mewujudkan suatu ekonomi rakyat yang berkembang - meminjam jargon yang sangat terkenal - dari rakyat, oleh rakyat, dan untuk rakyat.

\section{Metodologi Penelitian}

\section{A. Metode, Tempat dan Waktu} Penelitian.

Metode penelitian secara survey kasus terhadap responden di Wilayah Provinsi Riau yang merupakan daerah operasional PT. PER dan debitur terpilih dan waktu penelitian dari 2016 sampai 2019. 


\section{B. Pengambilan Responden}

Responden dalam penelitian ini adalah pegawai dan debitur PT. PER yang berjumlah 61 orang yang terdiri dari pimpinan 10 orang dan debitur 51 orang.

\section{Teknik Pengumpulan Data}

Metode pengumpulan data yang digunakan penulis dalam penelitian ini yaitu Interview, Yaitu melakukan wawancara langsung dengan pimpinan PT. PER dan debitur dan Kuesioner, yaitu merupakan pengumpulan data yang dilakukan dengan cara memberi pertanyaan tertulis kepada responden.

\section{Teknik Analisa Data}

Analisis data dalam penelitian ini dengan menggunakan analisis deskriptif yang bersifat kualitatif dan analisis induktif, dilakukan untuk melihat peranan PT. PER dalam memberdayakan atau meningkatkan ekonomi rakyat Riau secara profesional dalam bidang kewirausahaan yang dinamis, berdaya tahan dan progresif, selaras dengan dengan Visi Riau 2020.

Data yang diperlukan dalam melihat peranan PT. PER menyalurkan kredit kepada masyarakat meliputi nama debitur, alamat tempat tinggal, nama usaha, alamat usaha, sektor ekonomi, kegiatan usaha, besar plafond kredit, umur dan jangka waktu kredit dan pekerjaan dengan cara membuat
Daftar Pertanyaan dan fomulir Profil Debitur PT. PER. Data yang dibutuhkan adalah berhubungan dengan type karakteristik Usaha Mikro, Kecil, Menengah dan Koperasi (UMKMK) baik perorangan, berkelompok, badan usaha dan bakulan.

\section{IV.HASIL PENELITIAN \& PEMBAHASAN}

\section{A. Hasil Penelitian}

Berdasarkan hasil penelitian, maka Pada tahun 2007, Provinsi Riau mempunyai wilayah administrasi terdiri atas 12 (sebelas) Kabupaten/Kota, $10 \quad$ (sembilan) Kabupaten dan 2 (dua) Kota. Kabupaten/Kota di Provinsi Riau terbagi lagi menjadi 166 Kecamatan, 268 Kelurahan dan 1.591 Desa. Bila dibandingankan dengan tahun 2003, terjadi pengurangan jumlah Kabupaten/Kota dimana terdiri dari 16 Kabupaten/Kota, 12 Kabupaten dan 4 Kota. Hal ini disebabkan terjadinya pemekaran wilayah Provinsi Riau menjadi dua Provinsi yaitu Provinsi Riau sendiri dan Provinsi Kepulauan Riau yang terhitung 1 Juli 2004 resmi menjadi Provinsi ke 32 dari 34 Provinsi di Indonesia. Wilayah kerja PT. PER di Provinsi Riau berada di Kota Pekanbaru, Kota Dumai, Kabupaten Bengkalis - Duri, Kabupaten Rohul, Kabupaten Kuantan Singingingi, Kabupaten Indragiri Hulu dapat dilihat pada gambar 3 berikut ini 
Gambar 3.

Peta Wilayak kerja PT. PER di Provinsi Riau.

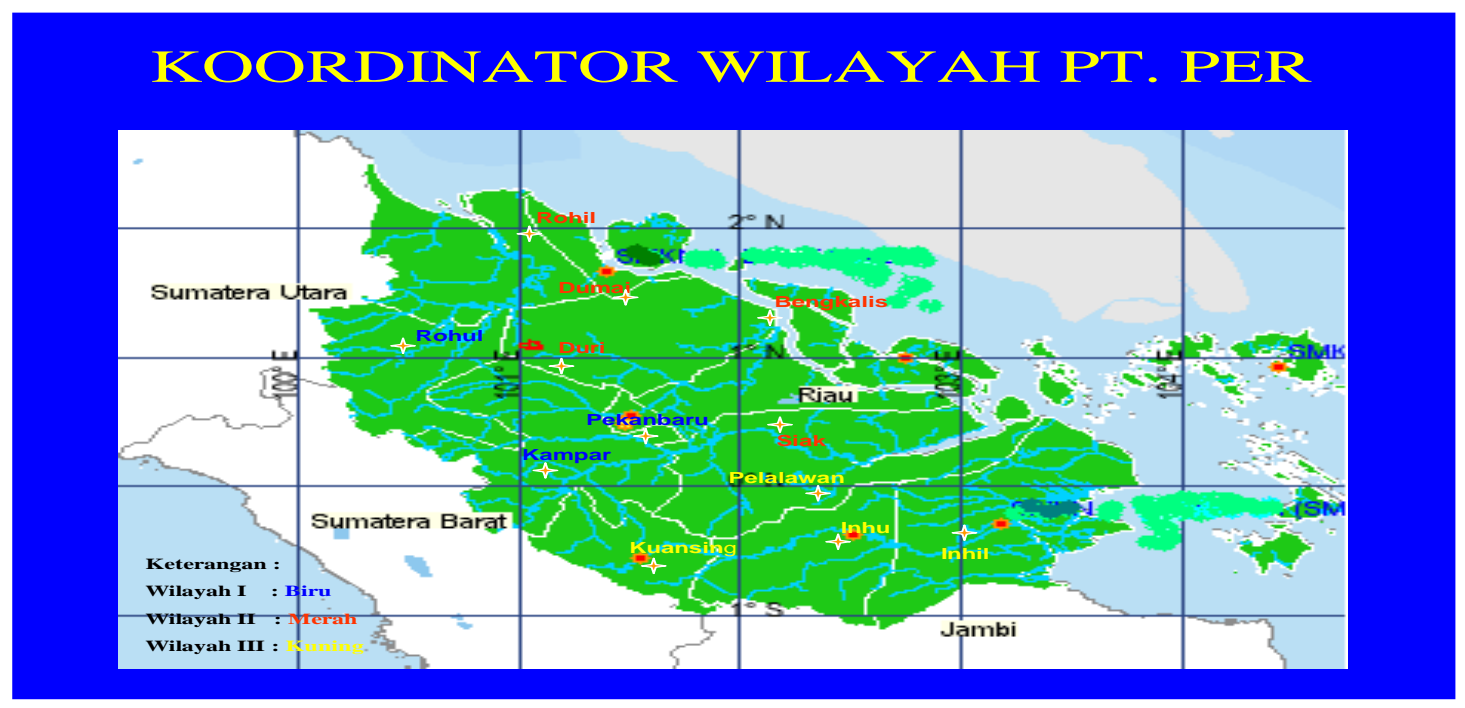

Sumber: PT. PER, 2016

Struktur ekonomi masyarakat di Provinsi Riau sepanjang tahun 2019 didominasi tiga lapangan usaha utama yaitu industry pengolahan, pertambangan dan penggalian, pertanian, kehutanan dan perikanan, mengidentifikasikan ada perubahan yang tahun lalu didominasi pertambangan sedangkan pertanian tetap. (RRI.co.id, 2019) sedangkan pada tahun-tahun sebelumnya struktur ekonomi Riau, terdapat tiga sektor yang memberikan kontribusi tertinggi yaitu : pertanian, industri, dan perdagangan. Sumbangan ketiga sektor itu pada pertumbuhan ekonomi Riau mencapai 80,93 persen (2005), diperkirakan meningkat mencapai 81,41 persen (2006), dan akan naik lagi menjadi sekitar 81,62 (2007).

Program dana begulir yang dijalankan Pemerintah Provinsi Riau pada tahun 2001 dan tahun 2002 melalui sejumlah Dinas ternyata tidak berjalan baik. Pengembalian dan bergulir tersebut sangat kecil.
Karena itu, Pemerintah Provinsi Riau dalam rangka efisiensi pengelolaan dana pemerintah yang saat itu dalam proses pemulihan ekonomi dengan dana yang terbatas, merasa perlu membangun Institusi berupa Lembaga Permodalan milik Pemerintah Provinsi Riau yang mandiri yang dapat diarahkan kegiatan operasionalnya sesuai dengan kebutuhan yang mendesak yang dihadapi pelaku ekonomi rakyat tanpa terikat oleh penjadwalan kegiatan menurut tahun anggaran sebagaimana yang berlaku pada proyek-proyek pemerintah serta dikelola secara profesional.

Hal itulah yang mendorong Pemerintah Provinsi Riau mendirikan Badan Usaha Milik Daerah (BUMD) PT. Permodalan Ekonomi Rakyat (PT. PER) sebagai Lembaga Keuangan Bukan Bank yang diharapkan dapat melaksanakan pemberdayaan dan pengembangan ekonomi rakyat Riau melalui penyaluran kredit kepada 
Usaha Mikro, Kecil dan Menengah (UMKM) baik dalam bentuk perorangan maupun berkelompok serta Lembaga Keuangan Mikro sebagai pelaku ekonomi rakyat dengan tujuan akhir peningkatan ekonomi masyarakat di Provinsi Riau.

Demikian pentingnya peranan PT. PER Provinsi Riau bagi masyarakat dan pembangunan daerah, maka perlu penyelenggaraan dan pembinaan yang didasarkan pada asas ekonomi yang sehat.

Berkaitan dengan fungsi PT. PER sebagai BUMD yang berusaha untuk menghasilkan laba sebagai salah satu sumber PAD, permodalan Usaha Mikro, Kecil Menengah dan Koperasi (UMKMK) terbantu, lapangan kerja terbuka dan modal penyertaan Pemda berkembang. Dalam kegiatannya dituntut untuk berperan sebagai lembaga perantara keuangan yang mampu bersaing secara sehat dengan lembaga keuangan sejenisnya. Kemampuan PT. PER dalam menyalurkan kredit kepada masyarakat rata-rata $0,41 \%$ per tahun dari total plafond kredit yang direalisasikan oleh perbankan di Provinsi Riau untuk sektor UMKM.

Kondisi Objektif PT. Permodalan Ekonomi Rakyat (PER) menjalankan aktivitas dengan Pola Pinjaman Modal adalah melalui a) Bank Perkreditan Rakyat (BPR) / BPRS, yaitu dalam bentuk executing maupun dalam bentuk channeling berdasarkan perjanjian kerjasama antara BPR/S dengan PT PER yang dibuat dihadapan Notaris dan selanjutnya BPR/S tersebut yang menyalurkan pinjaman modal kepada usaha kecil dan sederhana dengan syarat-syarat yang disepakati bersama antara kedua belah pihak, b) Melalui Lembaga Keuangan Mikro yaitu Sama seperti kepada BPR/S, dalam pola ini. PT PER menyalurkan dana kepada Lembaga Keuangan Mikro seperti BMT, Koperasi (termasuk Koperasi Swamitra), UED-SP, P4K, LPT Indag dll yang memenuhi syarat dan kriteria yang ditentukan PT PER dan sesuai dengan misi PT PER. Penyaluran dana tersebut juga dilaksanakan berdasarkan perjanjian kerjasama antara PT PER dengan Lembaga Keuangan Non Bank tersebut yang dibuat dihadapan Notaris dan selanjutnya lembaga keuangan tersebut akan menyalurkan pinjaman kepada usaha kecil dan sederhana dengan syarat-syarat yang disepakati bersama antara kedua belah pihak, c) Penyaluran langsung oleh PT PE yaitu pola ini, penyaluran kredit dilakukan langsung oleh PT PER kepada calon debitur yang akan dibiayai baik yang dilakukan oleh Kantor Pusat (melalui Cabang Utama) maupun Perwakilan Perusahaan di daerah-daerah berdasarkan perjanjian kredit antara PT PER dengan debitur dihadapan Notaris setelah melalui analisa kelayakan kredit secara profesional.

\section{B. Pembahasan Hasil Penelitian}

1. Komitmen Pemerintah Provinsi Riau Pemberdayaan Ekonomi Rakyat.

Pendirian PT.Permodalan Ekonomi Rakyat (PER) dimaksudkan untuk turut menunjang terwujudnya Visi Riau 2020 yang ditetapkan dalam Peraturan Daerah No. 36 Tahun 2001 tentang Pola Dasar Pembangunan Daerah Riau yaitu "Terwujudnya Propinsi Riau sebagai Pusat Pertumbuhan Ekonomi dan Budaya Melayu, dalam 
lingkungan Masyarakat yang Agamis, Sejahtera lahir dan bathin di Asia Tenggara Tahun 2020”.

Untuk mewujudkan visi tersebut dilakukan dengan melaksanakan salah satu misi yaitu Pemberdayaan Ekonomi Rakyat, didukung oleh infrastruktur yang kuat. Pada era kepemimpinan Gubernur Riau, Bapak H.M. Rusli Zainal dikenal dengan program mengentaskan kemiskinan, memerangi kemiskinan, kebodohan dan pembangunan infrastruktur (K2I).

2. Pelayanan Perusahaan dalam meningkatkan penyaluran kredit Manajemen semaksimal mungkin untuk memberikan pelayanan kepada masyarakat, langkah-langkah yang telah dilaksanakan antara lain :

a. Pendelegasian wewenang. Yaitu untuk lebih meningkatkan dan mempercepat pelayanan kredit kepada calon debitur, manajemen mengambil kebijakan berupa pendelegasian kewenangan memutus dan menyetujui kelayakan kredit kepada Kantor Perwakilan.

b. Penambahan Kantor Perwakilan Sejak tahun 2004 sampai 2019 dibuka kantor perwakilan yaitu di Teluk Kuantan Kabupaten Kuantan Singingi, di daerah-daerah yang potensial disamping pelayanan di Kantor Pusat, sehingga sampai akhir tahun 2019 PT. PER memiliki 6 kantor perwakilan yaitu di Dumai, Duri, Air Molek, Pekanbaru, Ujung Batu dan Teluk Kuantan. Pembukaan kantor perwakilan dimaksudkan untuk semakin mendekatkan dan mempercepat tersalurnya kredit secara langsung kepada masyarakat yang bermukim di Kecamatan, Desa dan kampung yang terdapat di pinggir sungai, pantai dan hutan yang belum mampu berhubungan dengan lembaga perbankan konvensional yang mempunyai aturan ketat.

Menyalurkan kredit secara tepat, cepat, mudah dengan suku bunga di bawah rata-rata suku bunga perbankan dengan tetap menekankan faktor kehati-hatian, serta meningkatkan sistem pelayanan kredit kepada masyarakat pedesaan dalam upaya menunjang program otonomi desa dan K2I Pemerintah Provinsi Riau. Membuka lapangan kerja bagi tenaga lulusan Perguruan Tinggi dan bagi penduduk setempat.

c. Penambahan skim kredit

Sejak tahun 2007 PT. PER menambah jenis skim kredit baru yaitu berupa kredit perumahan (Kenari Graha) bagi Debitur berpenghasilan tetap terutama Pegawai Negeri Sipil (PNS) yang termasuk dalam kelompok kredit Konsumtif.

d. Memperbanyak mitra penyaluran kredit

Sejak tahun 2007 PT. PER berupaya menambah mitra kerja terutama untuk marketing yaitu dengan penunjukan Kontributor di daerah-daerah yang potensial, disamping mitra yang sudah ada pada tahun-tahun sebelumnya.

e. Kemudahan jaminan kredit

Mengenai jaminan/agunan kredit, PT. PER memberikan kemudahan-kemudahan. Untuk jaminan berupa tanah, selain tanah dengan dokumen berupa sertifikat tanah juga bisa dengan SKGR (Surat Keterangan Ganti Rugi) atau SKT (Surat Keterangan Tanah) yang dikeluarkan Lurah/Kepala Desa dan diketahui Camat. Selain itu jaminan dapat juga berupa kendaraan bermotor serta tanggung renteng melalui kelompok.

f. Penambahan jumlah analis kredit 
Penentuan layak atau tidak layaknya kredit yang akan dikucurkan adalah kewenangan Komite Kredit yang anggotanya berasal dari unit-unit kerja di PT. PER dari berbagai keahlian dan latar belakang pendidikan. Prosesnya dimulai dengan melakukan analisis kredit oleh Analis Kredit yang berada di Kantor Pusat maupun Kantor Perwakilan dengan cara mengunjungi calon debitur dan tempat usaha calon debitur, melihat dan melakukan taksasi nilai jaminan dan selanjutnya Analis Kredit menyusun Analisis Kelayakan Kredit (AKK). Hasil dari AKK dibahas oleh Komite Kredit dan selanjutnya diputuskan kelayakannya. Guna meningkatkan pelayanan kredit.

3. Peran PER dalam pemberdayaan UMKM. Usaha yang dilakukan PT. PER yaitu

a. PT. PER memperluas jangkauan kredit ke sektor riil karena potensi kredit di sektor riil ini cukup besar dan tahan banting dengan cara penambahan kantor perwakilan di setiap Kabupaten/Kota di Provinsi Riau, memperbanyak mitra penyaluran kredit, pendelegasian kewenangan memutus kelayakan dan pencairan kredit, memberikan kemudahan jaminan kredit serta penambahan jumlah analis kredit.

b. Penyediaan Skim Kredit untuk UMKM dengan syarat lunak.

c. Menyalurkan dana kredit Channeling kepada BPR/S di Provinsi Riau. Penyaluran dana dengan pola Channeling didasarkan atas kesepakatan ataupun perjanjian kerjasama dengan pihak-pihak penyedia dana dan disalurkan sesuai dengan ketersediaan dana dan waktu yang telah ditetapkan. d. Bersama Dinas/Badan dan Lembaga lainnya melakukan kerjasama dalam pembinaa dan penyuluhah UMKM secara teradministrasi dan profesional dalam rangka meningkatkan pendapatan dan kesejahteraannya.

e. Meningkatkan pengetahuan dan ketrampilan serta sikap masyarakat agar mampu melaksanakan dengan baik kegiatan usahanya untuk meningkatkan sumber penghasilan dan pendapatannya.

f. Dalam rangka menumbuh kembangkan Usahanya tersebut masyarakat didorong dan digerakkan untuk memanfaatkan PT. Permodalan Ekonomi Rakyat (PER) yang dapat memberikan pelayanan kebutuhan kredit untuk usaha produktif mereka.

g. Membantu memberikan pertimbangan dalam memilih jenis usaha yang akan dikembangkan dengan pelayanan kredit.

4. PT. PER sebagai anggota KKMB Binaan BI

Konsultan keuangan/

Pendamping UMKM Mitra Bank (KKMB) yaitu : Perorangan atau lembaga yang telah dibekali dengan keterampilan khusus untuk dapat melakukan kegiatan pendampingan teknis dan manajerial kepada UMKM sehingga menjadi ' bankable'.

Prinsip Dasar pembentukan
KKMB
adalah $\begin{array}{r}\text { Program } \\ \text { Pemberdayaan KKMB dilaksanakan }\end{array}$
dengan mengacu pada prinsip kehati-
hatian oleh bank, ditujukan untuk
meningkatkan kemampuan UMKM
dalam berhubungan dengan bank,
misal dalam menyusun bankable
proposal, perencanaan usaha,


laporan keuangan dll dan BI sebagai fasilitator.

5. Kisah-kisah hidup debitur penerima kredit dari PT. PER terpilih sebanyak 14 debitur.

Dengan jumlah debitur PT. PER sejak tahun 2007 melebihi 2.707 orang. Maka dengan ini peneliti ingin melihat sumbangsih PT. PER kepada debiturnya dalam meningkatkan ekonomi masyarakat serta semangat kewirausahaan melalui kisah-kisah hidup debitur terpilih karena kegigihan mereka, filosofi hidup dan pengalaman hidup yang akan menjadi teladan bagi orang lain. PT. PER punya kewajiban untuk menumbuhkan dan memberdayakan ekonomi rakyat Riau secara profesional dalam bidang kewirausahaan yang dinamis, berdaya tahan dan progresif selaras dengan Visi Riau 2020 adalah pemberdayaan ekonomi rakyat, didukung oleh infrastruktur yang kuat.

Program K2I (Mengentaskan Kemiskinan, kebodohan dan membanguna infrastruktur). PT. PER dalam menjalankan kegiatan usahan mendukung program K2I dengan cara menyediakan modal, jasa manajemen dan kegiatan lain yang berkaitan dengan pengembangan usaha mikro, kecil dan menengah (UMKM), baik perorangan maupun berkelompok.

Sehingga tidaklah heran apabila sebagian besar debitur terpilih ini berasal dari kalangan masyarakat ekonomi lemah alias miskin. Sekarang dengan kerja keras, doa dan modal, mereka semua sudah sukses ataupun paling tidak, sedang menuju arah itu. "Ya, tak ada orang yang mau miskin terus". Inilah kisah-kisah hidup dan pengalaman usaha dari debitur yang dibiayai PT. PER untuk meningkatkan pendapatan dan taraf hidupnya antara lain :

a. Kisah-kisah debitur penerima kredit dari PT.PER ada kesamaannya antara Muhammad Yunus (Penerima Anugerah Nobel Perdamaian dari Bangladesh) yaitu a) Memudahkan prosedur peminjaman, tidak begitu ketat lazimnya sebuah lembaga perbankan, b) Menjadikan debitur sebagai asset, memperlakukan mereka dengan pembinaan dan rasa empati seperti yang dirasakan oleh seorang debitur Sdr. Masrizal, salah seorang pedagang plastik di pasar Senggol Kota Dumai. PT. PER member keringanan dalam hal pengangsuran utang sekaligus menawarkan bantuan modal baru sebesar Rp. 50 juta, dana tersebut digunakan untuk membuka usaha baru.

b. Hal yang buat terharu dari pengalaman debitur yaitu kemudahan peminjaman yakni tidak perlu izin usaha, tidak berbelit-belit, serta jumlah dana yang diterima sama dengan yang disetujui, tidak ada pemotongan sepeser pun. Mendapati kenyataan demikian debitur tersebut berucap PT. PER bagaikan orang tua yang meminjamkan uang kepada anaknya.

c. PT. PER punya peranan penting dalam memberikan efek ganda (multiplier effect) dalam peningkatan ekonomi masyarakat karena telah beroperasi di 8 Daerah Tingkat II dari 11 Kabupaten Kota yang ada di Provinsi Riau melalui Kantor Perwakilan dan Kontributor.

d. Usaha mikro, kecil, menengah dan Koperasi (UMKMK) serta Lembaga Keuangan Bank (BPR/S) dan 
Lembaga Keuangan Mikro (UEK/D-SP, BMT), Kelompok Tani dan lain-lain yang selama ini sulit memperoleh modal usaha, sebagian sudah dapat diatasi melalui kredit dari PT. PER.

e. Dengan adanya kredit dari PT. PER membuka lapangan kerja bagi masyarakat sebagai dampak dari kredit yang diberikan, misalnya kredit yang diberikan kepada kelompok tani perkebunan sawit, berdampak pada terbukanya lapangan kerja dari masyarakat untuk pembersihan dan pemeliharaan kebun, pendodos sawit, penjual pupuk, kegiatan transportasi dan lain-lain.

f. Pemanfaatan penyertaan modal Pemerintah Provinsi Riau di PT. PER dirasakan manfaatnya untuk pembinaan usaha mikro, kecil dan menengah serta koperasi. Dengan demikian, usaha masyarakat tertolong, uang daerah tidak habis percuma dan Pemerintah Provinsi Riau memperoleh hasil berupa PAD.

6. Dampak dan Manfaat keberadaan PT PER

Selama PT. PER berdiri sejak tahun 2003 sampai 2019, sudah mulai dirasakan dampak positif dari penyaluran kredit oleh PT. PER kepada masyarakat yaitu :

a. Kegiatan usaha para debitur PT. PER baik perorangan maupun Lembaga Keuangan Bank (BPR/S) maupun Non Bank mulai berkembang dengan cukup sukses.

b. Penyaluran kredit berdampak positif juga kepada penyerapan tenaga kerja. Dalam catatan PT. PER melebihi 4.719 orang tenaga kerja telah terserap oleh kegiatan usaha pra debitur yang dibiayai oleh PT. PER.
c.Kredit yang disalurkan PT. PER kepada usaha mikro, ternyata telah mampu membangkitkan semangat berusaha masyarakat seperti digambarkan dari Kisah-kisah hidup debitur penerima kredit dari PT. PER.

d. Dampak positif lainnya yang dirasakan adalah bahwa PT. PER telah turut membina perilaku masyarakat menuju Bank Manded, sebagaimana diakui oleh sejumlah Pimpinan Perbankan di Riau.

e.Manfaat yang di harapkan dari kegiatan adalah berkembangnya usaha mikro, kecil, menengah dan koperasi dan meningkatnya kesejahteraan masyarakat.

\section{KESIMPULAN DAN} SARAN

\section{Kesimpulan}

1. Pada umumnya debitur yang dibiayai PT. PER berkembang dengan cukup sukses dan mampu membangkitkan semangat berusaha masyarakat.

2. Minat usaha mikro, kecil dan menengah (UMKM) untuk memperoleh kredit dari PT. PER cukup besar termasuk yang disalurkan kepada debitur melalui BPR/S, UED/K-SP, Koperasi, BMT dan Kelompok Tani. Persentase penyaluran kredit masih didominasi sektor jasa $(51,50 \%)$, menyusul sektor perdagangan $21,9 \%$, sektor pertanian $19,6 \%$ dan sektor lainnya yaitu $7,0 \%$. Sebagian besar atau $54,78 \%$ plafond kredit dibawah Rp. 50 juta per debitur dan sisanya atau $45,22 \%$ plafond kredit diatas Rp. 50 juta per debitur.

3. Kisah-kisah sukses hidup dari debitur yang penerima pinjaman dari PT. PER menyatakan 
permodalan sangat mendukung perkembangan usaha dan kehidupan, mempekerjakan orang dalam jumlah yang tidak sedikit agar bisa bisa memenuhi target kerja, bisa membantu ekonomi keluarga dan membantu dunia usaha kecil dan menengah sehingga masyarakat usaha kecil banyak yang terbantu.

\section{Saran}

Berdasarkan kesimpulan di atas, maka dapat diberikan beberapa saran sebagai berikut:

1. Untuk menjalankan peran PT. PER sebagai lembaga permodalan maka dalam rangka membantu Pemerintah dalam peningkatan ekonomi masyarakat di Provinsi Riau dapat dilakukan upaya-upaya sebagai berikut : a) pemberdayaan UMKM di Provinsi Riau oleh PT. PER pada skala usaha yang sudah tumbuh supaya lebih ditingkatkan seperti Program Pemberdayaan Desa (PPD),UED/K-SP dan Program Pengembangan Lembaga Ekonomi Pedesaan dan lain-lain. b) peningkatkan fungsi dan peran lembaga permodalan dan lembaga kemasyarakatan demi mewujudkan kesejahteraan masyarakat melalui: Peningkatan partisipasi masyarakat dan meningkatkan penyaluran kredit untuk mengembangkan usaha modal kerja masyarakat, c) pemfokuskan diri pada penyaluran kredit kepada usaha super mikro dengan plafond maksimal Rp. 5 juta rupiah sama dengan program yang dijalan oleh Muhammad Yunus tanpa agunan serta tanggung renteng. supaya lebih menyentuh kepada masyarakat kecil, d) pengadopsi konsep dari Muhamad Yunus Penerima Hadiah Nobel Perdamaian yaitu sistem kredit tanpa agunan atau tanggung renteng karena penilaian kredit tidak harus berdasarkan agunan, tetapi berdasarkan prospek kegiatan usaha, e) pengaktifkan pendampingan kepada debitur dan membantu pemasaran.

2. Melakukan pembenahan manajerial sehingga tercipta manajemen yang profesional dengan melalakukan perbaikanperbaikan sebagai berikut : a) menetapkan rencana kerja tahunan sebagai acuan kegiatan usaha tanpa adanya revisi ditengah jalan, b) pencatatan transaksi agar dilakukan secara akurat dan laporan keuangan disusun sesuai dengan standar akuntansi yang berlaku, c) meningkatkan pengawasan terhadap pelaksanaan kegiatan bawahan, d) meningkatkan pemantauan dan pencatatan kredit yang jatuh tempo untuk mencegah kemungkinan timbulnya kesulitan likuiditas, e) meningkatkan peran Dewan Komisaris dan Komite Auditnya dalam melaksanakan pengawasan terhadap operasional PT. PER.

3. Menerapkan GCG (good and clean governance) lebih difokuskan pada pemberdayaan dan penguatan personil perusahaan melalui:Badan pengawasan Intern dan Pemantapan badan usaha, ada kewenangan unit kerja serta Keterbukaan birokrasi. 


\section{DAFTAR PUSTAKA}

Alhabsji, Syamsudin dan Soedjoto, 1987, "Kedudukan dan Peranan Perusahaan Daerah dalam Pelaksanaan yang Nyata dan Bertanggungjawab". Laporan Penelitian Kerjasama BAPPEDA Provinsi Jawa Timur dengan Universitas Brawijaya.

Bayu Krisnamurthi, 2001, Jurnal Ekonomi Rakyat "Pemberdayaan Ekonomi Rakyat: Strategi Revitalisasi Perekonomian Indonesia" CSIS- Bina Swadaya, Jakarta

Devas, Nick, Brian Binder, Anne Booth, Kenneth Davey fan Roy Kelly, 1989, Keuangan Pemerintah Daerah di Indonesia, UI-Press, Jakarta.

Peraturan Daerah Provinsi Riau, 2002, Nomor 19 Tahun 2002 tentang " Pembentukan Badan Usaha Milik Daerah (BUMD) Perseroan Terbatas (PT) Permodalan Ekonomi Rakyat",.

RRI.co.id, 2019, Struktu Perekonomian Riau Berubah, KBRN, Tanggal akses 26 Juni 2019 